\title{
Managing fishery impacts on deep-water coral ecosystems of the USA: emerging best practices
}

\author{
T. F. Hourigan* \\ National Oceanic and Atmospheric Administration, National Marine Fisheries Service, Office of Habitat Conservation,
} 1315 East-West Highway, Silver Spring, Maryland 20910, USA

\begin{abstract}
The USA has rich and varied deep-water coral ecosystems. Disturbances from bottom trawls have been well documented in certain habitats and are considered the major threat to deepwater corals in most US regions where such fishing is allowed. Other bottom-set fishing gears (e.g. gillnets and longlines) can also impact these communities. The USA has taken far-reaching action to address these threats to deep-water habitats. Since 2006, the USA has protected nearly 1.8 million $\mathrm{km}^{2}$ of vulnerable benthic habitats from bottom trawling, mostly in the Pacific. Additional major habitat conservation efforts are underway in the US Atlantic. In these efforts, a number of approaches are emerging as best-practices to conserve deep-water corals and other vulnerable marine ecosystems in the deep sea: (1) protecting particularly vulnerable areas, especially seamounts and major identified deep-water coral habitats, from impacts by all bottom-contact gear; (2) defining the current 'footprint' of bottom-trawl and dredge fisheries in partnership with the fishing community, and preventing expansion of these fisheries into deeper waters until they can be surveyed to identify potentially vulnerable habitats; and (3) using fisheries observers and vessel monitoring systems to provide key information that can inform adaptive management and enforcement. In 2006, the Magnuson-Stevens Fishery Conservation and Management Act, the nation's primary fishing law, was amended to explicitly allow protection of deep-sea corals in their own right. These approaches are being incorporated into a national strategic plan to comprehensively study and conserve deep-water coral and sponge ecosystems, and may help inform ongoing international conservation efforts.
\end{abstract}

KEY WORDS: Deep-sea coral • Vulnerable marine ecosystems . Essential fish habitat . Fishing impacts $\cdot$ Trawling $\cdot$ Marine conservation $\cdot$ Marine protected areas

\section{INTRODUCTION}

Fishing activities rank among the most widespread anthropogenic impacts to the world's oceans, and there has been increasing attention to the impacts of fishing gear on vulnerable benthic habitats, including those in the deeper ocean. New discoveries of extensive and biologically rich deep-water coral habitats in the 1990s galvanized action to protect discrete coral habitats (Freiwald et al. 2004, Davies et al. 2007). Deep-water corals, also known as deep-sea or cold-water corals, are generally slow-growing and fragile, making them and their associated communities vulnerable to humaninduced impacts, particularly physical disturbance.
Disturbances to deep-water coral communities from bottom-tending fishing gear, especially bottom-trawl gear, are well documented and pose the most widespread threat (Rogers 1999, Koslow et al. 2000, Fosså et al. 2002, Hall-Spencer et al. 2002, Grehan et al. 2005, Wheeler et al. 2005, Waller et al. 2007). Most protection efforts to date have focused on these threats. As a result of new discoveries, a number of countries have protected known deep-water coral areas within their exclusive economic zones (EEZ) since 1999, followed more recently by international action on the part of Regional Fishery Management Organizations/Agreements (RFMO/As) in areas beyond national jurisdiction (Davies et al. 2007, Hourigan 2008). 
The USA has the world's largest EEZ, covering over 11 million $\mathrm{km}^{2}$, and containing rich and varied deep-water ecosystems as well as diverse demersal fisheries. In 2007 , the first major assessment of US deep-water coral ecosystems (Lumsden et al. 2007) revealed that these habitats are likely much more extensive and important to ocean ecosystems than previously known. The full extent of habitats suitable for deep-water corals in the US EEZ was not estimated, and only a tiny fraction of areas below $200 \mathrm{~m}$ depth has been surveyed for corals. The report reviewed the distribution of known deep-water coral habitats and the threats they face. As elsewhere, disturbances from bottom-contact fishing gears are well documented and considered among the most widespread and serious threats to structure-forming deep-water corals in most US regions where such fishing is allowed. The National Research Council (NRC 2002) concluded that bottom trawling and dredging reduce habitat complexity by removing or damaging the physical structure of the seafloor and by causing changes in species composition. The present study reviews US efforts to address fishing impacts on vulnerable deep-sea habitats, particularly deep-water corals, and highlights approaches that are emerging as US best-practices in the context of ecosystem approaches to fisheries management.

\section{MANAGING IMPACTS OF US FISHERIES ON DEEP-WATER CORALS}

\section{Threats to US coral habitats from fishing operations}

Hourigan et al. (2007) reviewed major potential fishing and non-fishing stressors to US deep-water coral communities and summarized perceived levels of current threats for 7 US regions. The regions were delineated based on the Regional Fishery Management Council (RFMC) jurisdictions, but correspond generally to large marine ecosystems (with the exception of the US Pacific Islands and Alaska, which encompass several large marine ecosystems). Each region has different deep-water coral communities, different intensities of use, and different levels of information on the actual impacts of potential stressors. With the exception of a few areas, such as the relatively shallow Oculina Banks off the east coast of Florida, the full extent of habitat degradation resulting from anthropogenic impacts is largely unknown. Nevertheless, based on the best available data, disturbance to deep-water coral communities from bottomtending fishing gear, especially bottom-trawl gear, was identified as the major concern in most regions where such fishing is allowed. Bottom trawling was the only threat identified as a high concern in Alaska, the Pacific West Coast, the US Northeast and the US Southeast. With the exception of the US Southeast, these regions have large commercial bottom-trawl fisheries that operate at depths where deep-water corals occur. Disturbances to corals from bottom trawls have been documented in Alaska (Krieger 2001, Stone 2006). Prior to recent management actions, the National Marine Fisheries Service (NMFS) estimated that, from 1997 to 1999, Alaska groundfish fisheries (primarily bottom trawling for fish) removed an extrapolated average of approximately 5 metric tons ( $\mathrm{t}$ ) of coral annually as bycatch in the Gulf of Alaska and $40 \mathrm{t}$ in the Bering Sea and Aleutian Islands (NMFS 2004). Along the US Pacific coast, bottom trawls accounted for over $92 \%$ of observed coral bycatch between August 2001 and 2004 (Whitmire \& Clarke 2007). The Gulf of Mexico, where bottom trawling was ranked by regional experts as a low to medium threat, and the US Southeast, where it was ranked as a high threat, primarily have only small rock shrimp Sicyonia brevirostris or royal red shrimp Pleoticus robustus trawl fisheries and calico scallop Argopecten gibbus dredge fisheries that potentially operate in areas that contain deep-water corals. However, Koenig et al. (2005) estimated that $90 \%$ of Oculina banks had been damaged by trawling by 2001. Fishing with bottom trawls or dredges is not permitted in the EEZ of the US Pacific Islands or US Caribbean.

Other bottom-set fishing gears, including gillnets, longlines, pots and traps have also been identified as potentially damaging to deep-water corals, and were ranked as low to medium threats to deep-water coral communities in all regions except the US Pacific Islands and US Caribbean, where they were rated as low (Hourigan et al. 2007). In federal waters of the US Pacific EEZ, the use of bottom-set gillnets is prohibited. Fixed gear (e.g. bottom-set gillnets and longlines) may be easier than trawls to fish with on rougher substrates where corals occur, which may increase the chances of interactions with corals.

Among non-fishing threats that can directly impact deep-water coral communities, only oil and gas development (in the Gulf of Mexico), precious coral harvests and invasive species (both in Hawaii) were considered medium-level threats (Hourigan et al. 2007). Other potential activities, such as cable deployment, were identified as low threats. There is, however, increasing awareness of the potentially serious consequences of climate change and ocean acidification to these communities, but there is insufficient information at present to ascribe to them a specific threat level.

\section{Fisheries management approaches in the US EEZ}

NOAA is the principal federal agency responsible for management of living marine resources within the US EEZ where most US deep-water coral communities 
occur. NOAA manages fisheries in the EEZ through fishery management plans developed by 8 Regional Fishery Management Councils (RMFCs) and NMFS. A list of current and proposed fishery management plans is available at www.nmfs.noaa.gov/sfa/domes_fish/ FMPS2.htm. This system emphasizes local participation and allows adaptation to biological and social characteristics of regional fisheries. It also results in different approaches to protecting deep-water corals and other vulnerable benthic habitats in different regions, within the overall framework set out by US legislation, principally the Magnuson-Stevens Fishery Conservation and Management Act (MSA; 16 USC 1801 et seq.). While lacking national consistency, the regional delineation described earlier means that regions can be viewed as laboratories for exploring different management approaches.

To date, management approaches by NOAA and the Councils to reduce fishery impacts on deep-water corals have primarily relied upon either treating the corals themselves as managed species (e.g. precious corals), or protecting habitats that include deep-water corals which have been identified as essential fish habitat $(\mathrm{EFH})$ for other managed fisheries species (Hourigan et al. 2007). The Councils have taken a number of actions to reduce interactions between fishing gears and vulnerable habitats, including reductions of fishing effort, and gear modifications such as reducing footrope or roller size on bottom-trawls. In recent years, however, the main approach to minimize fishing impacts on EFH has concentrated on prohibiting the use of selected bottom-contact gears in specific geographic areas. Areas closed year-round to mobile bottom-tending gear represent a subset of marine protected areas (MPAs), and have been identified as the most effective approach to protect biogenic habitats such as deep-water corals and sponges (NRC 2002). Table 1 gives areas in federal waters that contain deep-water corals and have been closed to trawling, where at least part of the justification was to reduce impacts on the habitats.

In 2006, Congress reauthorized the MSA, requiring that NOAA establish a 'Deep Sea Coral Research and Technology Program' and providing new discretionary authorities to the RFMCs to protect deep-sea corals in their own right (rather than as EFH for managed fisheries species) from fishing impacts. This further reflected the growing awareness of the value of such deep-water habitats. The first report to Congress on implementation of the program (NOAA 2008) included an initial list of areas known to contain deep-sea coral habitats for the Councils to evaluate for potential protection as allowed under the discretionary provisions of the amended MSA.

\section{Protection of specific deep-water coral habitats}

In the early 1980s, the South Atlantic Fishery Management Council (FMC) recommended, and NOAA established, the world's first area to protect deepwater azooxanthellate coral habitat, the Oculina Bank Habitat Area of Particular Concern (HAPC) off Florida. Over the following $15 \mathrm{yr}$, there were no explicit efforts to conserve deep-water coral habitats, though NOAA received new authorities to identify and protect EFH in the reauthorization of the MSA in 1996. In 2000, the Oculina Bank HAPC was expanded and the Sitka Pinnacles Marine Reserve off Alaska was established. The latter prohibited all bottom-fishing and anchoring and protects a small area with high-relief habitat, including red tree corals Primnoa pacifica and other corals, that is associated with aggregations of lingcod Ophiodon elongatus and juvenile and adult rockfish Sebastes spp. Although primarily established to protect the fish aggregations, this may be the first area protected with special consideration for deep-water gorgonians, rather than reef-building scleractinian corals, and reflects a broadening of interest by managers in other structure-forming coral taxa. The presence of coral resources in the reserve has been documented, but not fully inventoried.

Deep-water corals and sponges are known to occur in Oceanographer Canyon and Lydonia Canyon located on the southern flank of Georges Bank in the western Atlantic. In 2005, under EFH authority, these canyons (an area totaling $400 \mathrm{~km}^{2}$ ) were closed to fishing for monkfish Lophius americanus using bottomcontact gear. The following year, in the Gulf of Mexico, several banks and ridges containing zooxanthellate stony corals, as well as deeper communities of octocorals and black corals, were protected under regulations developed in cooperation with the Flower Garden Banks National Marine Sanctuary.

The most coordinated protection efforts directed specifically at deep-water coral habitats have occurred in federal waters off Alaska using EFH authority. In 2006, NOAA approved comprehensive measures recommended by the North Pacific FMC to minimize the adverse effects of fishing on EFH. These measures included banning all bottom-contact fishing gear from 6 Aleutian Islands Coral Garden Habitat Protection Areas and 5 Primnoa Coral Habitat Protection Areas in the Gulf of Alaska (Table 1). The Gulf of Alaska has areas of dense stands of red tree corals Primnoa pacifica, and gorgonians appear to reach their highest diversity in US waters in the Aleutian Islands, often forming structurally complex 'coral gardens' with lace corals, sponges and other sedentary taxa (Stone 2006, Stone \& Shotwell 2007). 


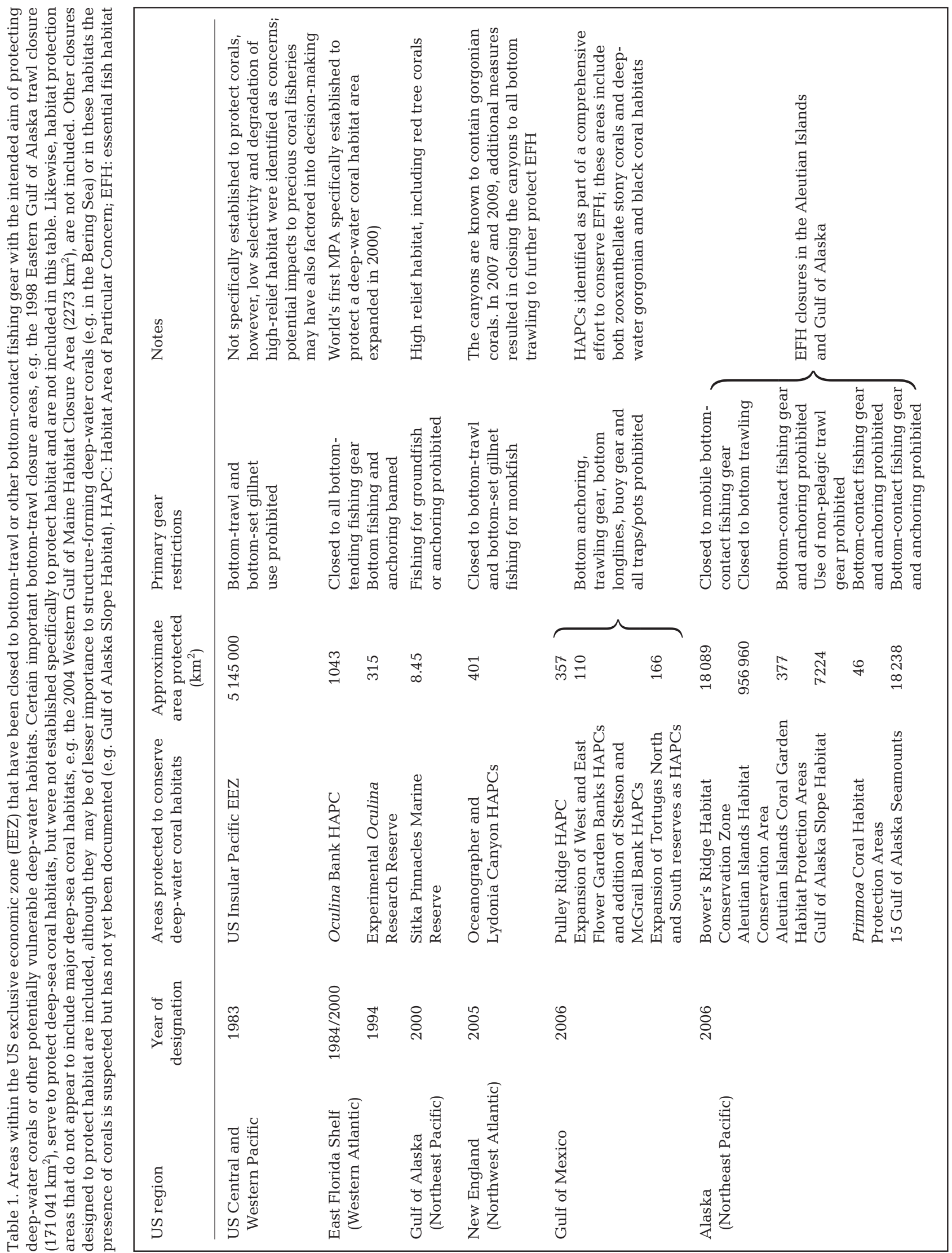




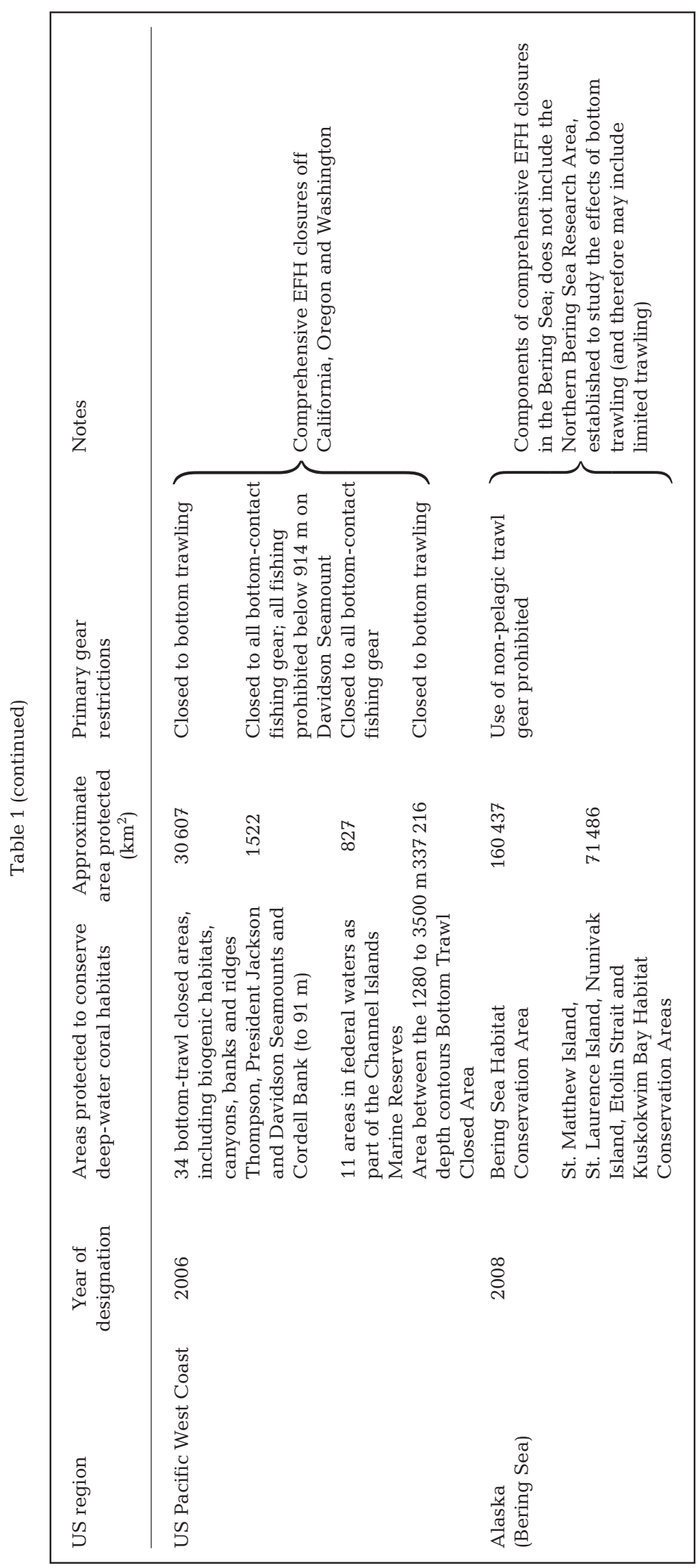

\section{Protection of habitat features and seamounts associated with deep-water coral areas}

The measures to protect specific, documented deep-water coral areas outlined above are important, but the areas are relatively small, ranging from less than $10 \mathrm{~km}^{2}$ (Sitka Pinnacles) to just over $1000 \mathrm{~km}^{2}$ (Oculina Bank HAPC). They have often been given the highest levels of protection (e.g. all bottom-contact gear prohibited), but they represent just a small portion of the likely extent of deep-water coral habitatsgenerally those for which there has been ground-truthing by submersible or remotely operated vehicle. Trawl surveys and reports of coral bycatch indicate much broader coral distributions (Stone \& Shotwell 2007, Whitmire \& Clarke 2007). In the 2006 comprehensive EFH measures in the EEZ off both the US West Coast and Alaska, additional areas were closed to bottom trawling based on less direct evidence or on topographical or geological features known to be associated with biogenic habitats, including deepwater corals. Bowers Ridge in the Bering Sea and 10 Gulf of Alaska Slope Habitat Conservation Areas were closed to mobile bottom-contact gear or bottom trawling, respectively. Off California, Oregon and Washington, 34 areas were closed to trawling, including portions of undersea canyons (e.g. Monterrey Canyon), banks (e.g. Heceta Bank) and ridge systems (e.g. Mendocino Ridge), as well as identified biogenic habitats. In most cases, these topographic features were associated with hard substrata known to be colonized by corals, sponges and other fauna. Together, these areas offer a much larger area of protection to known and potential deep-water coral habitats than do the areas protecting specific deep-water coral habitats.

Seamounts are major topographic features that have been recognized as important conservation targets both in the USA and in ongoing international negotiations to protect vulnerable marine ecosystems, where they represent the most common location of deep-sea fisheries on the high seas. In US waters, the comprehensive EFH measures for Alaska recognized that seamounts are isolated features that may serve as stepping stones for migratory species or become habi- 
tat for resident species settling on these features far offshore of slope and shelf habitats. Of 24 named seamounts in the EEZ off Alaska, 16 rise to fishable depths $(<3000 \mathrm{~m})$. Although only 5 of these have been sampled, the North Pacific FMC recommended, and NOAA approved, closing all 16 seamounts to all bottom-contact fishing gear. In a similar manner, 3 large seamounts off the coasts of Washington (Thompson Seamount), Oregon (President Jackson Seamounts) and California (Davidson Seamount) were protected from all bottom-contact gear. In November 2008, Davidson Seamount was incorporated into an expanded Monterey Bay National Marine Sanctuary, providing further protection from threats other than fishing.

In the Atlantic, the New England and South Atlantic FMCs, with technical assistance from NOAA and regional coral experts, are also working to increase knowledge of and protection for deep-water corals. The New England FMC is revising EFH descriptions, designating 15 deep-sea canyons and portions of 2 seamounts as HAPCs. These contain structure-forming organisms (e.g. deep-water corals and sponges) recognized by the Council as unique habitats important to conservation and sustainable fisheries management. The HAPC designation alone does not necessarily convey protection. In a second phase, the Council will analyze the impacts of fishing on EFH and recommend appropriate management measures to be implemented within the HAPCs or elsewhere. The South Atlantic FMC has proposed designation of 4 Deepwater Coral HAPCs off North Carolina, South Carolina, Georgia and the Atlantic coast of Florida, covering an area greater than $59000 \mathrm{~km}^{2}$ and including the greatest abundance and development of deep-water scleractinian coral reefs in US waters. Within the proposed HAPCs, use of all bottom-tending fishing gear and anchoring (by fishing vessels) would be prohibited.

\section{Applying a precautionary approach: 'freezing the footprint' of trawl fisheries}

A third conservation approach is to restrict the geographic expansion into currently unfished areas by the most potentially destructive fishing techniques, generally bottom-trawl and dredge fisheries. This approach, often referred to as 'freezing the footprint' of the fishery, takes a precautionary approach to habitat protection, rather than requiring proof that vulnerable habitats exist before restrictions on trawling are enacted. This may be especially applicable to protecting deepwater coral habitats, where the costs of surveying areas are prohibitive and the potential for long-term damage to fragile and slow-growing biogenic species is great.
In 2006, this precautionary approach formed the centerpiece of new habitat protections enacted in the Aleutian Islands and off the US West Coast. Within the suite of EFH measures, the Aleutian Islands Habitat Conservation Area prohibited the use of non-pelagic trawl fishing gear in designated areas of the Aleutian Islands where such gear had not yet been heavily used in order to reduce the effects of fishing on deep-water corals, sponges and hard-bottom habitats, while allowing historically fished areas to remain open to such fishing. Covering over 950,000 $\mathrm{km}^{2}$, this conservation area represents the largest single effort in recent years to conserve relatively undisturbed bottom habitats in US waters. In March 2007, the Alaska Board of Fisheries adopted regulations, at the request of NOAA and the North Pacific FMC, to apply these management measures to state-managed fisheries in both state and federal waters. Ongoing work will assess the change in deep-water coral bycatch by commercial fishing vessels as a result of the conservation measures.

In 2008, companion conservation measures went into force to protect benthic fish habitat in the Bering Sea from the potential effects of bottom trawling and to provide the opportunity to further study the effects of such trawling on bottom habitat. These measures also included areas closed to bottom trawling in locations that have not been previously fished with such gear (e.g. Bering Sea Habitat Conservation Area) and in nearshore bottom habitat areas that support subsistence marine resources. True soft corals are the major species occurring in these areas (Stone \& Shotwell 2007), and although the closures were not designed specifically to protect deep-water corals, they reflect the enhanced use of precautionary measures in the US Pacific.

A comparable 'freeze the footprint' approach was also implemented in 2006 as part of the comprehensive EFH conservation measures proposed by the Pacific FMC. The plan was developed in collaboration with non-governmental organizations, the fishing industry and NOAA's National Marine Sanctuary Program to focus largely on pristine or untrawled habitat in conjunction with the more targeted conservation measures described above. Areas between the 1280 to $3500 \mathrm{~m}$ depth contours off the US West Coast were closed to bottom trawling, and include areas known to harbor deep-water corals. The South Atlantic FMC has proposed to 'freeze the footprint' of the golden crab Chaceon fenneri fishery, representing a similar effort to control the geographic expansion of impacts, but addressing another type of bottom-contact gear, i.e. traps.

The nation's largest precautionary gear closures, however, are also its oldest. In 1983, the Western Pacific FMC recommended and NOAA implemented a prohibition on the use of bottom-trawl gear and bottom-set gill nets - identified as threats to deep-water corals - 
within all federal waters around the state of Hawaii, the territories of American Samoa and Guam, the Commonwealth of the Northern Mariana Islands and the US Pacific Island possessions. These conservation steps have been further strengthened by the establishment of Marine National Monuments in the Northwestern Hawaiian Islands in 2006 (Papahānaumokuākea Marine National Monument), and Rose Atoll, Pacific Remote Islands and Marianas Trench in 2009.

\section{CONCLUSIONS}

The USA has taken far-reaching action to address impacts of fishing gear on vulnerable deep-water habitats. These domestic actions include many elements (e.g. identification of vulnerable benthic habitats, environmental assessments and observer coverage) that foreshadowed the International Guidelines for the Management of Deep-sea Fisheries (FAO 2008) adopted by the UN Food and Agriculture Organization in 2008. The efforts in the Pacific also pioneered precautionary approaches such as 'freezing the footprint' of bottom-trawl fisheries, an approach that was subsequently implemented as an interim measure in international negotiations for regional agreements to establish RFMOs to regulate high seas bottom fisheries in the Northwest Pacific and South Pacific. In certain cases, especially with regard to protecting seamounts from all types of bottom gear, US conservation provisions go well beyond provisions currently envisioned on the high seas.

Since 2006, the USA has protected nearly 1.8 million $\mathrm{km}^{2}$ of potentially vulnerable benthic habitats from bottom trawling in the US Pacific and Bering Sea. The protections, pursuant to the MSA, are intended to minimize adverse effects from fishing on EFH. Included in those protected areas are major deep-water coral habitats. Together, these protections reflect the following US best practices to conserve vulnerable marine ecosystems in the deep sea:

- Area-based management measures addressed multiple deep-water biogenic habitats (e.g. corals, sponges and bryozoans) over large geographic regions.

- Areas known to support luxuriant deep-water coral resources, e.g. Aleutian Islands 'coral gardens' and Primnoa coral areas in the Gulf of Alaska were protected from all bottom-contact gear.

- Seamounts in both the Gulf of Alaska and off the US West Coast were recognized as representing unique ecological characteristics and protected from all bottom-contact gear. This reflects the growing awareness of the ecological importance of seamounts (Clark et al. 2006).
- Recognizing that many unsurveyed areas may contain important biogenic habitats, the 'footprint' of bottom-trawl fisheries was defined in partnership with the fishing community, and expansion of these fisheries into deeper waters was prohibited until untrawled areas can be surveyed to identify potentially vulnerable habitats.

- These area-based measures were complemented by provisions that enhance successful implementation, e.g. federally permitted trawl vessels operating in US waters off Alaska are required to carry a transmitting vessel monitoring system, and vessels over $125 \mathrm{ft}$ in length $(38 \mathrm{~m})$ are required to have $100 \%$ coverage of fisheries observers in order to provide key information that can inform management and enforcement.

- These efforts also incorporated streamlined amendment procedures to aid in adaptive management as new information becomes available.

In 2010, NOAA will publish a 'Strategic Plan for Deep-sea Coral and Sponge Ecosystems', designed to integrate these regional approaches into a comprehensive ecosystem management framework on a national level. The primary goal of the plan is to improve research, conservation and management of deepwater coral and sponge ecosystems. As NOAA, in partnership with the RFMCs, is the federal agency responsible for managing fisheries in the EEZ, managing fishing threats to these communities is one primary focus of this strategic plan. The strategic plan's conservation and management objectives specific to fisheries include:

- Protection areas containing known deep-sea coral or sponge communities from impacts of bottomtending fishing gear.

- Protection areas that may support deep-sea coral and sponge communities where mobile bottom-tending fishing gear has not been used recently, as a precautionary measure.

- Developing regional approaches to further reduce interactions between fishing gear and deep-sea corals and sponges.

Acknowledgements. Thanks go to R. Stone, J. Olson, S. Copps, M. Brouwer, T. Bigford and T. Lederhouse for helpful reviews. The views expressed in this paper are those of the author and do not necessarily represent the policy of the USA or NOAA.

\section{LITERATURE CITED}

Clark MR, Tittensor D, Rogers AD, Brewin P and others (2006) Seamounts, deep-sea corals and fisheries: vulnerability of deep-sea corals to fishing on seamounts beyond areas of national jurisdiction. UNEP-WCMC, Cambridge, available at www.unep-wcmc.org/resources/publications/ UNEP_WCMC_bio_series/25.htm 
Davies A, Roberts JM, Hall-Spencer JM (2007) Preserving deep-sea natural heritage: emerging issues in offshore conservation and management. Biol Conserv 138:299-312

FAO (Food and Agriculture Organization) (2008) Report of the technical consultation on international guidelines for the management of deep-sea fisheries in the high seas. FAO Fisheries and Aquaculture Report No. 881, FAO, Rome

Fosså JH, Mortensen PB, Furevik DM (2002) The deep-water coral Lophelia pertusa in Norwegian waters: distribution and fishery impacts. Hydrobiologia 471:1-12

Freiwald A, Fosså JH, Grehan A, Koslow T, Roberts JM (2004) Cold-water coral reefs. UNEP-WCMC, Cambridge

Grehan AJ, Unnithan V, Olu-Le Roy K, Opderbecke J (2005) Fishing impacts on Irish deepwater coral reefs: making a case for coral conservation. In: Barnes PW, Thomas JP (eds) Benthic habitats and the effects of fishing. Am Fish Soc Symp 41:819-832

Hall-Spencer J, Allain V, Fosså JH (2002) Trawling damage to northeast Atlantic ancient coral reefs. Proc R Soc Lond B Biol Sci 269:507-511

Hourigan TF (2008). The status of cold-water coral communities of the world: a brief update. In: Wilkinson C (ed) Status of coral reefs of the world: 2008. Global Coral Reef Monitoring Network, Reef and Rainforest Research Centre, Townsville, p 57-66

Hourigan TF, Lumsden SE, Dorr G, Bruckner AW, Brooke S, Stone RP (2007) Deep coral ecosystems of the United States: introduction and national overview. In: Lumsden SE, Hourigan TF, Bruckner AW, Dorr G (eds) The state of deep coral ecosystems of the United States. NOAA Tech Memo CRCP-3, Silver Spring, MD, p 1-64

Koenig CC, Shephard AN, Reed JK, Coleman FC, Brooke SD, Brusher J, Scanion KM (2005) Habitat and fish populations of the deep-sea Oculina coral ecosystem of the Western Atlantic. In: Barnes PW, Thomas JP (eds) Benthic habitats and the effects of fishing. Am Fish Soc Symp 41:795-805

Koslow JA, Boehlert GW, Gordon JDM, Haedrich RL, Lorance P, Parin N (2000) Continental slope and deep-sea fisheries: implications for a fragile ecosystem. ICES J Mar Sci 57: 548-557

Krieger KJ (2001) Coral (Primnoa) impacted by fishing gear in the Gulf of Alaska. In: Willison JH, Hall J, Gass SE, Kench-

Submitted: December 12, 2008; Accepted: February 9, 2009 ington ELR, Butler M, Doherty P (eds) Proc 1st Int Symp Deep-Sea Corals. Ecology Action Centre, Halifax, p 106-116

Lumsden SE, Hourigan TF, Bruckner AW, Dorr G (eds) (2007) The state of deep coral ecosystems of the United States. NOAA Tech Memo CRCP-3, Silver Spring, MD, available at www.nmfs.noaa.gov/habitat/dce.html

NMFS (National Marine Fisheries Service) (2004) Alaska groundfish fisheries final programmatic supplemental environmental impact statement. Department of Commerce, NOAA, NMFS, Alaska Region, Juneau, AK

NOAA (2008) Report to Congress on the implementation of the deep sea coral research and technology program. Department of Commerce, NOAA, Silver Spring, MD

NRC (National Research Council) (2002) Effects of trawling and dredging on seafloor habitat. National Academy Press, Washington DC

Rogers AD (1999) The biology of Lophelia pertusa (Linnaeus 1758) and other deep-water reef-forming corals and impacts from human activities. Int Rev Hydrobiol 84: 315-406

Stone RP (2006) Coral habitat in the Aleutian Islands of Alaska: depth distribution, fine-scale species association, and fisheries interactions. Coral Reefs 25:229-238

Stone RP, Shotwell SK (2007) State of deep coral ecosystems in the Alaska region: Gulf of Alaska, Bering Sea and the Aleutian islands. In: Lumsden SE, Hourigan TF, Bruckner AW, Dorr G (eds) The state of deep coral ecosystems of the United States. NOAA Tech Memo CRCP-3, Silver Spring, $\mathrm{MD}, \mathrm{p}$ 65-108

Waller R, Watling L, Auster P, Shank T (2007) Anthropogenic impacts on the Corner Rise Seamounts, NW Atlantic Ocean. J Mar Biol Assoc UK 87:1075-1076

Wheeler AF, Bett BJ, Billett DS, Masson DG, Mayor D (2005) The impact of demersal trawling on northeast Atlantic coral habitats: the case of the Darwin Mounds, United Kingdom. Am Fish Soc Symp 41:807-817

Whitmire CE, Clarke ME (2007) State of deep coral ecosystems of the U.S. Pacific Coast: California to Washington. In: Lumsden SE, Hourigan TF, Bruckner AW, Dorr G (eds) The state of deep coral ecosystems of the United States. NOAA Tech Memo CRCP-3, Silver Spring, MD, p 109-154

Proofs received from author(s): December 15, 2009 